\title{
RECENT ADVANCES IN UNDERSTANDING ELECTROSLAG REMELTING METALLURGY OF SUPERALLOYS
}

\author{
L. Gao \\ J. Fu \\ C. $X$. Chen
}

Beijing University of Iron and Steel Technology

Rapid development has been attained in the last decade in ESR metallurgy of superalloys. G. K. Bhat (1) predicted that for most of high performance alloys vacuum arc remelting would be replaced by the ESR process in the early eighties.

In China, ESR technology has been adopted for superallsy manufacturing since 1962. Most of the wrought iron and nickel base high temperature alloys are now made by the ESR process, and the ESR-casting process has been developed to make large turbine discs and other components. The research results obtained in China-in particular, at the University, the Da ye Steel Plant, Fushun Steel Plant and the Ben Xi Steel Plant-are discussed in this review paper. These results also are discussed with respect to the world literature on ESR.

\section{CONTROL OF TITANIUM AND ALUMINUM}

It is well known that the control of titanium and aluminum is the key problem during ESR of superalloys (2). Investigations have been carried out with the following results $(3-5)$.

\section{Effect of $\left(\mathrm{TiO}_{2}\right)$ on Titanium Loss}

In order to suppress titanium loss during remelting, many authors have suggested the use of "balanced slag system" containing $\mathrm{TiO}_{2}(6-10)$. Under laboratory and industrial con-

*Invited Paper 
ditions, it has been found that (3):

During the ESR of superalloys GH132 and GH136 (similar to the U.S.A. alloys $A-286$ and $V-57$, respectively) with $\mathrm{CaF}_{2}-$ $\mathrm{Al}_{2} \mathrm{O}_{3}-\mathrm{TiO}_{2}$ slag system, $\mathrm{TiO}_{2}$ causes the oxidation of [Ti]* and [A1] and results in titanium loss by the following reactions at the metal-slag interface.

$$
\begin{gathered}
{[\mathrm{Ti}]+3 \mathrm{Ti}{ }^{4+}=4 \mathrm{Ti}^{3+}} \\
4[\mathrm{~A} T]+3 \mathrm{Ti}{ }^{4+}=4 \mathrm{~A} 7^{3+}+3[\mathrm{Ti}]
\end{gathered}
$$

It is believed that $\mathrm{Ti}^{3+}$ was transferred to slag-atmosphere interface and reoxidized at the slag-atmosphere interface by atmospheric oxygen. The titanium and aluminum loss rates $V_{m-s} I^{3+}$ and $V A I_{-s}{ }^{+}$can be expressed respectively by the following equations:

$$
\begin{gathered}
\left.V_{\mathrm{m}-\mathrm{S}}^{T i^{3+}}=\left\{-\Delta[\mathrm{Ti}] \cdot 4 \mathrm{~W} / 100 \mathrm{M}_{\mathrm{Ti}}\right\}+\{-\Delta[\mathrm{A}]] \cdot 3 \mathrm{~W} / 100 \mathrm{M}_{\mathrm{A}}\right\} \\
\left.V_{\mathrm{m}-\mathrm{S}}^{A 7^{3+}}=-\Delta[\mathrm{Al}] \cdot \mathrm{W} / 100 \mathrm{M}_{\mathrm{A}}\right\}
\end{gathered}
$$

where $M_{T i}$ and $M_{A}$ are the gram-atomic weights of [Ti] and [AI], respectively, and $-\Delta[\mathrm{Ti}]$ and $-\Delta[\mathrm{A} 1]$ are the differences in contents of $T_{i}$ and $A T$ between remelted metal and consumable electrode, respectively; $W$ is the remelting rate in gram per $\mathrm{sec}$. The effects of $\left(\mathrm{TiO}_{2}\right)$ on $\mathrm{VT}_{\mathrm{T}}^{\mathrm{j}}{ }^{3+}$ and $\mathrm{VA}_{\mathrm{m}}^{\mathrm{A}} \mathrm{I}^{3+}$ are shown in Figs. 1 and 2. It can. be seen that the titanium and aluminum losses increase with increasing (Ti02). From the equilibrium constants of the reactions $\mathrm{Ki}$ defined in Fig. 3 which is evaluated from thermodynamic data (11), it can be seen that, as values of $\mathrm{K}_{6}$ and $\mathrm{K}_{7}$ are quite large, $\mathrm{TiO}_{2}$ will oxidize [Ti] and the oxidation products vary with the activity of $\left(\mathrm{TiO}_{2}\right)$. They may be $\mathrm{Ti}_{3} \mathrm{O}_{5}, \mathrm{Ti}_{2} \mathrm{O}_{3}$ or $\mathrm{TiO}$ ( $\mathrm{Fig}$. 3). Calculations show that at $1700^{\circ} \mathrm{C}$, if a $\left(\mathrm{TiO}_{2}\right)>0.2849,0.2849>\mathrm{a}\left(\mathrm{TiO}_{2}\right)>0.0824$ or $\mathrm{a}\left(\mathrm{TiO}_{2}\right)<0.0824$, the oxidation products wi 11 be $\mathrm{Ti} 305$, $\mathrm{Ti}_{203}$ or $\mathrm{Ti0}$, respectively. Furthermore, as $\mathrm{K} 7$ is larger than $K_{5}$ and $K_{6}$, the main oxidation product would be $\mathrm{Ti}_{3} \mathrm{O}_{5}$.

$x$-ray structure analysis on solidified slag has shown

*[] denotes element or compound in the melt. () denotes in the slag. 
that a kind of slag with original composition of $76.65 \% \mathrm{CaF}_{2}$, $18.60 \% \mathrm{Al}_{2} \mathrm{O}_{3}$ and $4.75 \% \mathrm{TiO}_{2}$, transferred into another one with $\mathrm{CaF}_{2}, \mathrm{Caf}_{2} \cdot 5 \mathrm{Al}_{2} \mathrm{O}_{3}, \mathrm{CaTiO}_{3}$ and $\mathrm{Ti}_{3} \mathrm{O}_{5}$ after reacting with a 17oy GH136 in agreement with petrographic analysis.

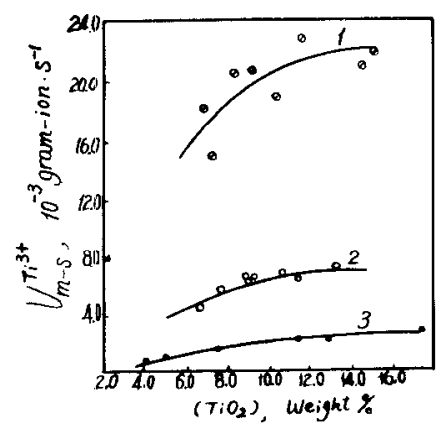

Fig. 1

Effect of $\left(\mathrm{TiO}_{2}\right)$ on $\mathrm{V}_{\mathrm{m}-\mathrm{s}}^{\mathrm{Ti}^{3+}}$

1 - $360 \mathrm{~mm}$ dia. mold

2 - $230 \mathrm{~mm}$ dia. mold

3 - $84 \mathrm{~mm}$ dia. mold

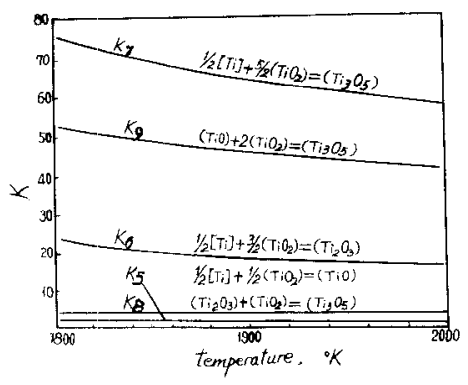

Fig. 3. Effect of temperature on the equilibrium constants of the reactions (5) - (9)

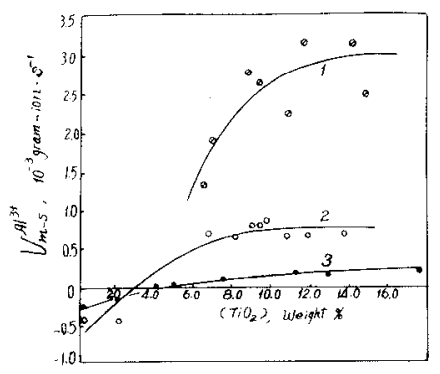

Fig. 2

Effect of $\left(\mathrm{TiO}_{2}\right)$ on $\mathrm{V}_{\mathrm{m}-\mathrm{S}}^{\mathrm{Al}}$

1 - $360 \mathrm{~mm}$ dia. mold

2 - $230 \mathrm{~mm}$ dia. mold

3 - $84 \mathrm{~mm}$ dia. mold

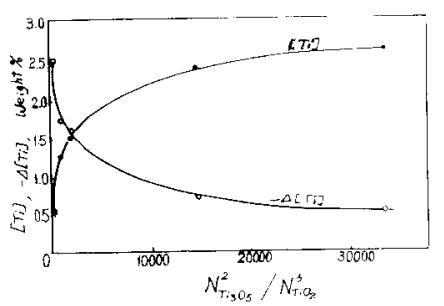

Fig. 4. Dependence of [Ti] and $-\Delta[\mathrm{Ti}]$ on $\mathrm{N}_{\mathrm{Ti}}^{2} \mathrm{O}_{5} / \mathrm{N}_{\mathrm{TiO}}^{5}$ 
The experimental results have shown that [Ti] increases and $-\Delta[\mathrm{Ti}]$ decreases with increasing $\mathrm{N}^{2} \mathrm{Ti} 305 / \mathrm{N}^{5} \mathrm{Ti} 02$ under equilibrium condition, Fig. 4. It can be seen that either excess or low $\left(\mathrm{TiO}_{2}\right)$ would not be advantageous to titanium control, Fig. 5. Under low $\left(\mathrm{TiO}_{2}\right)$ conditions, [A1] increases and [ $\left.\mathrm{Ti}^{\mathrm{C}}\right]$ decreases at the ingot bottom because of the oxidation reaction between [ $\mathrm{Ti}]$ and $\left(\mathrm{AT}_{2} \mathrm{O}_{3}\right)$. Therefore, in order to obtain sufficient homogeneity of titanium and aluminum in alloys, it is necessary to maintain a suitable amount of $\mathrm{TiO}_{2}$ in the original slag in accordance with the alloy composition. Experiments have shown that $3-6 \%$ of $\mathrm{TiO}_{2}$ is adequate, see Fig. 5 .

\section{Effect of $(\mathrm{MgO})$ on $[\mathrm{Al}]$ and $[\mathrm{Ti}]$ Loss}

C. F. Knights and R. Perkins (7) have investigated the distribution of elements between metal and slag during ESR of $\mathrm{A}-286$, using $\mathrm{CaF}_{2}-\mathrm{Al}_{2} \mathrm{O}_{3}-\mathrm{MgO} \mathrm{slag}$ system. Indeed, remelting titanium and aluminum bearing superalloys with $\mathrm{CaF}_{2}-\mathrm{Al}_{2} \mathrm{O}_{3}-\mathrm{Ca} 0$ -MgO slag system has been patented already (12).

The function of $\mathrm{MgO}$ in slag system of $\mathrm{CaF}_{2}-\mathrm{Al}_{2} \mathrm{O}_{3}-\mathrm{TiO}_{2}-$ $\mathrm{Ti}_{3} \mathrm{O}_{5}-\mathrm{MgO}$ also was studied in a recent investigation (3). It was found that (MgO) increased the coefficients of activity of $\left(\mathrm{Ti}_{3} \mathrm{O}_{5}\right)$ and $\left(\mathrm{Al}_{2} \mathrm{O}_{3}\right)$ and at the same time decreased the coefficient of activity of $\left(\mathrm{TiO}_{2}\right)$. The coefficients of activity of $\left(\mathrm{Ti}_{3} \mathrm{O}_{5}\right)$ and $\left(\mathrm{Al}_{2} \mathrm{O}_{3}\right)$ in slag system with $9 \% \mathrm{MgO}$ were 1.39 and 1.75 times, respectively, of that without $\mathrm{MgO}$, and the coefficient of activity of $\left(\mathrm{TiO}_{2}\right)$ in the same slag was only $38.7 \%$ of that in a MgO-free slag. Thus, it appears that (Mg0)

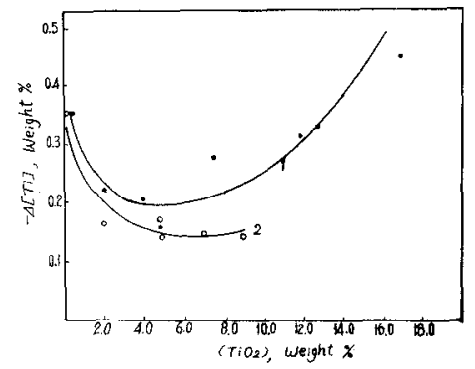

Fig. 5. Influence of $\left(\mathrm{TiO}_{2}\right)$ on the Titanium Loss at Ingot Bottom

1 - GH132, $84 \mathrm{~mm}$ dia. mold

2 - GH136, $230 \mathrm{~mm}$ dia. mold 
suppresses the oxidizing effect of $\left(\mathrm{TiO}_{2}\right)$.

It should be mentioned, however, that ESR operating variables can greatly affect [ $T i]$ loss. During remelting of alloy GH132 with MgO-bearing slag, [Ti] loss was found to increase considerably with increasing operating voltage. For example, under certain experimental conditions, [Ti] ioss increased by about $0.03 \%$ per increasing volt.

\section{Atmospheric Oxidation}

It is difficult to control [Ti] and [AT] loss under operating conditions just by regulating the composition of the slag system because the effect of atmospheric oxygen can, at times, control the situation.

In the ESR process, low valence titanium ion in the slag acts continuously as a transporter of oxygen via $\mathrm{Ti}^{4+}$ from the atmosphere to the me1t. Experiments have shown that $\left(\mathrm{Ti}_{3} \mathrm{O}_{5}\right)$ the concentration $\mathrm{CTi}^{3+}$ and the melt-to-slag velocity $\mathrm{VT}_{\mathrm{m}-\mathrm{S}}^{3+}$ were influenced by atmospheric oxygen. When the remelting process is carried out in air, ( $\left.\mathrm{Ti}_{3} \mathrm{O}_{5}\right)$ and $\mathrm{CTi}^{3+}$ are lower and $V_{w-s}^{T+3+}$ is higher than that in argon atmosphere, see Fig. 6 and pabre 1.

Effect of Temperature Distribution and Electrical Insulation on [Ti] and [AT] Losses

B. E. Poton, A. Mitche17, A. H. Dilawari et al. (13-17) and their coworkers studied the temperature fietd in molten

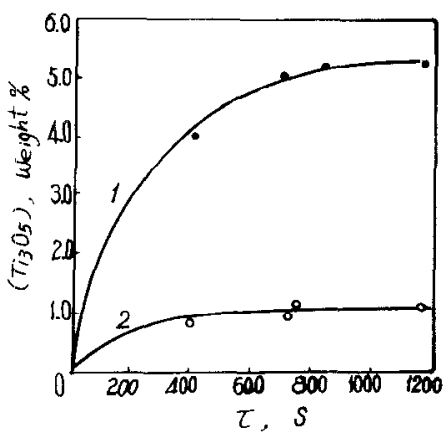

Fig. 6. Variation in $\left(\mathrm{Ti}_{3} \mathrm{O}_{5}\right)$ during Remelting as a Function of Time $\tau$

$$
1 \text { - in argon }
$$$$
2 \text { - in air }
$$ 
Table 1. Influence of Atmosphere on $\left(\mathrm{Ti}_{3} \mathrm{O}_{5}\right), \mathrm{C}_{\mathrm{Ti}} 3+$ and $\mathrm{VTi}_{\mathrm{m}-\mathrm{s}}{ }^{3+}$

\begin{tabular}{|c|c|c|c|c|}
\hline $\begin{array}{l}\text { Melt } \\
\text { No. }\end{array}$ & Atmosphere & $\underset{\%}{\left(\mathrm{Ti}_{3} \mathrm{O}_{5}\right)}$ & $\begin{array}{c}\mathrm{C}_{\mathrm{Ti}}{ }^{3+} \cdot 10^{4 *} \\
\text { gram-ion } \cdot \mathrm{cm}^{-3} \\
\end{array}$ & $\begin{array}{l}V_{m-5}^{T i^{3+}} \cdot 10^{3} \\
\operatorname{gram}-i o n \cdot s^{-1}\end{array}$ \\
\hline $\begin{array}{l}210 \\
211 \\
206 \\
207\end{array}$ & $\begin{array}{c}\text { Argon } \\
\text { Argon } \\
\text { Air } \\
\text { Air }\end{array}$ & $\begin{array}{l}5.2 \\
4.92 \\
0.85 \\
1.14\end{array}$ & $\begin{array}{r}12.45 \\
11.80 \\
2.03 \\
2.73\end{array}$ & $\begin{array}{l}0.60 \\
0.67 \\
1.70 \\
1.87\end{array}$ \\
\hline
\end{tabular}

* $\mathrm{C}_{\mathrm{Ti}^{3+}}=\left[\left(\mathrm{Ti}_{3} \mathrm{O}_{5}\right) \cdot 2 \mathrm{ps}\right] / 100 \mathrm{MTi}_{305}$, where $\rho \mathrm{s}$ is density of molten slag and $\mathrm{M}_{\mathrm{Ti} 3 \mathrm{O}_{5}}$ is molecular weight of $\mathrm{Ti}_{3} \mathrm{O}_{5}$.

slag pool under Taboratory conditions. The temperature distribution in molten slag pool under industrial conditions and its influence on [Ti] and [AI] losses have been investigated by this University, Da Ye Steel Plant, Fu Shun Steel Plant, Ben $X_{i}$ Steel Plant and $X_{i}$ Ning Steel Plant (4).

The temperatures measured along the axial direction at the middle of the distance between the cylindrical electrode surface and mold wa.11 are shown in Fig. 7 for a $360 \mathrm{~mm}$ industrial mold. The temperature profiles can be expressed roughly by

$$
t=1675 \exp (-1.074 / 1),(5 \mathrm{~mm} \leq 1 \leq 210 \mathrm{~mm})
$$

where $t$ is the slag temperature in ${ }^{\circ} \mathrm{C}$ and 1 is the distance below the slag-atmosphere interface in $\mathrm{mm}$.

The results obtained in the case of remeiting in the $500 \mathrm{~mm}$ and $230 \mathrm{~mm}$ diameter molds using $240 \mathrm{~mm}$ square and $95 \mathrm{~mm}$ round consumable electrodes, respectively, are shown in Fig. 8, which is approximately in agreement with Fig. 7. It was found that the surface temperature of slag pool and, in consequence, $\mathrm{V}_{\mathrm{m}} \mathrm{j}^{3+}, \mathrm{VAl}_{\mathrm{m}} \mathrm{3}^{+}, \mathrm{V}_{\mathrm{S}}{ }_{2}$ and $\mathrm{KT} \mathrm{T}^{3+}$ for electrically noninsulated mold ("ive moldigs are higher than those for insulated mold (Figs. 9, 10 and Table 2). The rate of oxygen transfer into the slag $\left(\mathrm{V}_{\mathrm{S}}^{-}\right)$and the reoxidation coefficient of $\mathrm{Ti}^{3+}\left(\mathrm{K}_{\mathrm{S}}^{\mathrm{T}} \mathrm{g}^{+}\right)$
can be expressed by the following equations: 


$$
\begin{gathered}
V_{S-g}^{O_{2}}=\left\{-\Delta[T i] \cdot W / 100 M_{T j}\right\}+\left\{-\Delta[A 1] \cdot 3 W / 4 \cdot 100 M_{A 1}\right\} \\
K_{S-g}^{T j^{3+}}=V_{S-g}^{T i^{3+}} \cdot A_{S-g}^{-1} \cdot C_{T j}^{-1} 3+
\end{gathered}
$$

$\mathrm{V}^{\mathrm{Ti}} \mathrm{i}^{3+}$ is the reoxidation rate of $\mathrm{Ti}^{3+}, \mathrm{A}_{\mathrm{S}-\mathrm{g}}$ is the area of siag atmosphere interface, and $\mathrm{C}_{\mathrm{Ti}}{ }^{3}+$ is the concentration of $\mathrm{Ti}^{37}$ in slag.

Remelting in a "live mold" caused a stranger tendency for aluminum to increase at the bottom-end. A110y GH136, which contains more titanium than alloy GH132, showed an even stronger tendency towards aluminum increase as shown in Fig. 10.

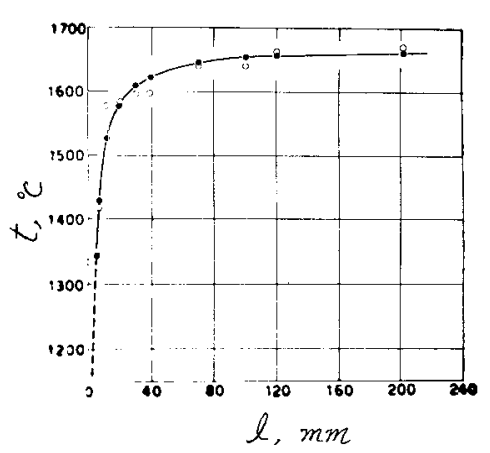

Fig. 7. The Axial temperature distribution in molten slag pool

$$
\begin{gathered}
\text { "o" - measured } \\
\text { "." - calculated by } \\
\text { Equation (10) } \\
360 \text { mm dia. mold }
\end{gathered}
$$

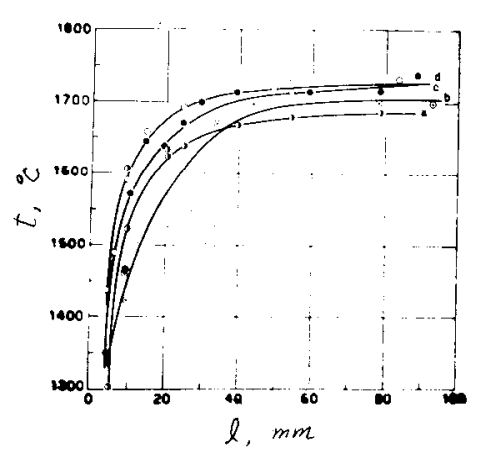

Fig. 8. The axial temperature distribution in molten slag pool*

* a $-500 \mathrm{~mm}$ dia. insulated mold, $\mathrm{CaF}_{2}-\mathrm{Al}_{2} \mathrm{O}_{3} \mathrm{slag}$

b - $230 \mathrm{~mm}$ dia. insulated mold, $\mathrm{CaF}_{2}-\mathrm{Al}_{2} \mathrm{O}_{3}-\mathrm{TiO}_{2} \mathrm{slag}$;

c $-230 \mathrm{~mm}$ dia. insulated mold, $\mathrm{CaF}_{2}-\mathrm{Al}_{2} \mathrm{O}_{3}-\mathrm{TiO}_{2}-\mathrm{MgO}$ slag;

d $-230 \mathrm{~mm}$ dia. "live mold," $\mathrm{CaF}_{2}-\mathrm{Al}_{2} \mathrm{O}_{3}-\mathrm{TiO}_{2}-\mathrm{MgO}$ slag. 


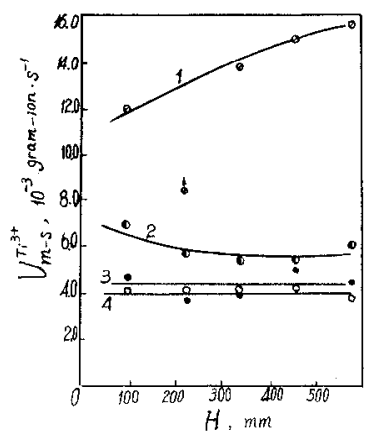

Fig. 9. Effect of insulated conditions on $V_{m-s}^{T i}$

1 - GH136, "1ive mold"

2 - GH136, insulated

3 - GH132, insulated $\mathrm{CaF}_{2}-\mathrm{Al}_{2} \mathrm{O}_{3}-\mathrm{MgO}-\mathrm{TiO}_{2}$

4 - GH132, insulated $\mathrm{CaF}_{2}-\mathrm{Al}_{2} \mathrm{O}_{3}-\mathrm{TiO}_{2}$

$\mathrm{H}$ - the distance from the bottom of the ESR ingot

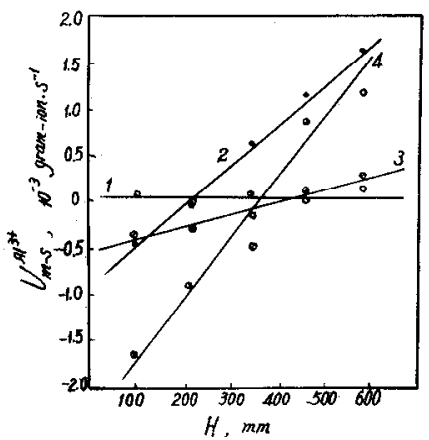

Fig. 10. Effect of insulated conditions on $\mathrm{V}_{\mathrm{m}-\mathrm{S}}^{A}$

1 - GH132, insulated

2 - GH132, "live mold"

3 - GH136, insulated

4 - GH136, "live mold"

$\mathrm{H}$ - the distance from the bottom of the ESR ingot

Table 2. Reoxidation Coefficient of $\mathrm{Ti}^{3+}$ at the Slag-Atmosphere Interface

\begin{tabular}{|c|c|c|c|c|c|c|}
\hline $\begin{array}{l}\text { Melt } \\
\text { No. }\end{array}$ & A1loy & Slag System* & $\begin{array}{c}\text { Mold } \\
\text { Cond' } n\end{array}$ & $\begin{array}{l}\text { Surface } \\
\text { Temp. }{ }^{\circ} \mathrm{C}\end{array}$ & $\begin{array}{l}\mathrm{KS}_{\mathrm{S}}^{\mathrm{Ti}} \mathrm{j}^{3+} \\
\mathrm{CM} \cdot \mathrm{S}^{-1}\end{array}$ & $\begin{array}{l}v_{\mathrm{S}}^{02} \mathrm{~g} \\
\mathrm{~mol} \cdot \mathrm{S}^{-1} \times 10^{3}\end{array}$ \\
\hline $52-29$ & GH136 & $\begin{array}{l}\mathrm{CaF}_{2}-\mathrm{Al}_{2} \mathrm{O}_{3}-\mathrm{MgO} \\
-\mathrm{TiO}_{2}\end{array}$ & Insulat. & 1350 & $7.19 \times 10^{-2}$ & 1.51 \\
\hline $52-27$ & GH136 & $\begin{array}{l}\mathrm{CaF}_{2}-\mathrm{Al}_{2} \mathrm{O}_{3}-\mathrm{MgO} \\
-\mathrm{TiO}_{2}\end{array}$ & Live & $1405 \geq$ & $\geq 1.86 \times 10^{-1}$ & 3.90 \\
\hline $52-44$ & GH136 & $\mathrm{CaF}_{2}-\mathrm{Al}_{2} \mathrm{O}_{3}-\mathrm{MgO}$ & Insulat. & 1350 & $2.47 \times 10^{-2}$ & 0.52 \\
\hline $52-50$ & GH136 & $\mathrm{CaF}_{2}-\mathrm{Al}_{2} \mathrm{O}_{3}-\mathrm{MgO}$ & Live & 1450 & $\geq 1.13 \times 10^{-1}$ & 2.39 \\
\hline $52-51$ & GH132 & $\mathrm{CaF}_{2}-\mathrm{Al}_{2} \mathrm{O}_{3}-\mathrm{MgO}$ & Insulat. & 1350 & $3.09 \times 10^{-2}$ & 0.65 \\
\hline $52-49$ & GH132 & $\mathrm{CaF}_{2}-\mathrm{Al}_{2} \mathrm{O}_{3}-\mathrm{MgO}$ & Live & $1450=$ & $\geq 1.36 \times 10^{-1}$ & 2.85 \\
\hline
\end{tabular}

*Data for final period of remelting. 
In the case in which the mold was electrically connected to the base plate, the temperature was found to be higher and the viscosity lower at the slag surface. These effects can be due to current passage, causing greater absorption of oxygen and more rapid reoxidation of $\mathrm{Ti}^{3+}$ and, hence, a greater loss of titanium.

On a previous work (7), the effects of temperature in the "high temperature region" on titanium and aluminum behavjor were described. It was found in the present work that various temperatures at the slag-atmosphere interfaces caused different losses of titanium and aluminum while the temperature in the "high temperature region" remained the same (Figs. 8-10).

\section{SURFACE QUALITY}

The temperature distribution at the me1t-slag interface has a great effect on the thermoconductivity. The radial temperature distribution in the molten slag pool can be expressed by the equation $t=A e^{B / d}(5)$, where $d$ is the distance from mold wall to electrode center, $A$ is a constant expressing approximately the temperature of the slag in the "high temperature region." Constant $A$ is found to be $1675^{\circ} \mathrm{C}$ under the experimental condition mentioned above for the mold of $360 \mathrm{~mm}$ in diameter. Constant $B<0$, representing the temperature change near the mold wa11, is affected by the heat transfer condition and the current density distribution in the slag pool. It can be determined by the melting point and thickness of the slag skin. For example, when the liquidus temperature and thickness of slag skin were $1400^{\circ} \mathrm{C}$ and $2 \mathrm{~mm}$, respectively, $\mathrm{B}=-0.359$. In this case $(5)$, the temperature distribution at the metal pool-slag interface is

$$
t=1675 \exp (-0.359 / d),(2 \mathrm{~mm} \leq d \leq 180 \mathrm{~mm})
$$

The surface quality of remelted ingots can be described in terms of the thickness change of slag skin during remelting process. The thickness of slag skin $(\delta)$ can be calculated (5) by the following equation:

$$
\delta=B /\left(\ln t_{1}-\ln A\right)
$$


where $t_{7}$ is the liquidus temperature of slag, ${ }^{\circ} \mathrm{C}$.

From the equation above it can be seen that $\delta$ increases with increasing of $|B|$ and $t_{1}$ and decreases with increasing of A (Fig. 11).

It is possible to analyse the effect of the remelting conditions on the surface quality of the ESR ingots in terms of Equation (14). The low input power, small slag resistance and great slag volume, etc., lead to the low values of $A$, and consequently a bad bottom-end structure would be found.

The second type of shunt current, as defined in Ref. 4, can alter the value of $B$ at the metal pool-slag interface, leading to a "shunt defect." A thickening of the slag skin, a pin hole, a tear drop or tear flow resulting in metal-tomold contact and a "necked" ingot are the symptoms of this type of defect as reported in Ref. 8. We found $t_{7}$, determined by slag composition, changed during remelting owing to metallurgical reactions. For example, during the remelting of a1loy GH132 in mold of $430 \mathrm{~mm}$ square with a slag containing $5 \% \mathrm{TiO}_{2}$, the concentration of $\left(\mathrm{THO}_{2}\right)$ in the later period of refining increased to more than 20\% owing to the oxidation reactions. In this case $t_{7}$ was higher than the melting temperature of the alloy (Table 3), and the defects--the solidified droplet and the scar of slag on the top surface of the ingot--appeared. When $t_{1}$ is lower than the melting temperature of metal, the liquid metal would "smooth" the original slag skin and lead to an even ingot surface.
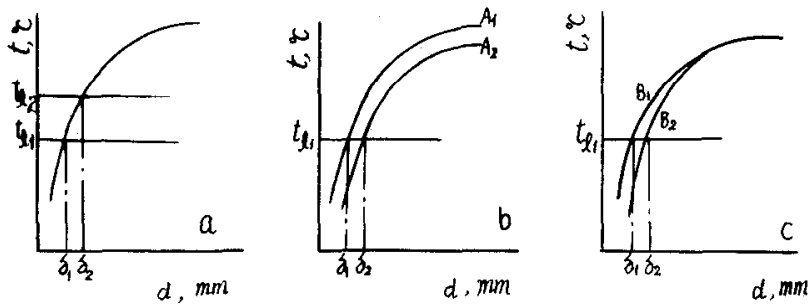

Fig. 11. Schematic showing the relations between the thickness of slag skin $(\delta)$ and $t_{1}, A$ and $B$ $a-t_{12}>t_{1}, \delta_{2}>\delta_{1} ; b-A_{2}<A_{1}, \delta_{2}<\delta_{1} ; c-|B|_{2}>|B|_{1}, \delta_{2}>\delta_{1}$ 
Table 3. Change of Composition and Melting Temperature of Slag during ESR Process

Composition, \%

No. Remelting Melting Time (hrs.) $\quad \mathrm{CaF}_{2} \quad \mathrm{Al}_{2} \mathrm{O}_{3} \quad \mathrm{CaO}_{2} \quad \mathrm{TiO}_{2} \quad$ Temp. ( $\left.{ }^{\circ} \mathrm{C}\right)$

\begin{tabular}{rrrrrrr}
\hline 1 & 0.0 & 72.07 & 18.74 & 1.23 & 4.64 & $1315-1358$ \\
2 & 2.0 & 68.60 & 13.05 & 0.92 & 13.93 & $1324-1374$ \\
3 & 3.7 & 62.40 & 12.95 & 0.96 & 17.00 & $1386-1391$ \\
4 & 4.9 & 57.72 & 10.91 & 1.01 & 20.18 & $1386-1399$ \\
\hline
\end{tabular}

CHANGE OF OXIDE INCLUSIONS DURING THE ESR PROCESS

It was found that the removal of oxide inclusions mainty occurs in the droplet formation step at the electrode tip owing to intensive interaction between metal and slag rather than flotation in the metal pool (18-20). This view has been supported by other authors (21-23) and was further confirmed in a recent investigation, using ${ }^{95} \mathrm{Zr}$ isotopes and other methods by Z. B. Li et al. of Central Institute of Iron and Stee 1 Research (24). The results are shown in Table 4.

Table 4. Relative Changes of Oxide Inclusions during ESR Process

\begin{tabular}{lllll}
\hline \multicolumn{1}{c}{ Data } & \multicolumn{2}{c}{$\begin{array}{c}\text { Quantitative } \\
\text { Metallographic Data } \\
(18)\end{array}$} & $\begin{array}{c}\text { Oxygen } \\
\text { Content } \\
(24)\end{array}$ & $\begin{array}{c}\text { Specific Intensity } \\
\text { of Radiation } \\
(24)\end{array}$ \\
\hline Sample & 100 & 100 & 100 & 100 \\
\hline $\begin{array}{l}\text { Electrode } \\
\begin{array}{l}\text { Droplet at } \\
\text { Electrode }\end{array}\end{array}$ & 23.2 & 32.2 & 52.4 & 43.3 \\
$\begin{array}{l}\text { Tip } \\
\text { Droplet in } \\
\text { Slag Pool }\end{array}$ & 13.0 & 23.7 & 38.1 & -- \\
$\begin{array}{l}\text { Metal Pool } \\
\text { Remelting }\end{array}$ & 18.5 & 22.5 & 33.3 & 15.3 \\
Ingot & 14.5 & -- & -- & 10.3 \\
\hline
\end{tabular}


As for thermodynamic conditions of metal-siag interaction for removing inclusions, equations given by different authors based on interface tensions appear contradictory.

$$
\begin{aligned}
& \sigma_{s-i}+\sigma_{m-s}<\sigma_{m-i}, \text { Ref. } 25 \\
& \sigma_{s-i}-\sigma_{m-s}<\sigma_{m-i}, \text { Ref. } 22,26-28
\end{aligned}
$$

D. Ya. Povolotski et al. suggested that the above equations could be derived from

$$
\sigma_{s-i}-\sigma_{m-s} \cdot \operatorname{Cos} \alpha<\sigma_{m-i} \text {, Ref. } 29
$$

where $\sigma_{\mathrm{s}-i}, \sigma_{\mathrm{m}-\mathrm{s}}$ and $\sigma_{\mathrm{m}-i}$ express the interfacial tensions of slag-inclusion, metal-slag and metal-inclusion interfaces, respectively, and a is a location parameter of an inclusion at the metal-slag interface. D. Ya. Povolotski substituted his interfacial energy data into Equation (17) and proposed that oxide inclusions would remain immobile at a metal-slag interface site where $\sigma_{s-i}-\sigma_{m-s} \cdot \cos \alpha=\sigma_{m-i}$. Hence, it was concluded that the removal of inclusions must be accomplished by inclusion dissolution at this position.

S. A. Eodcovski (26) and O. D. Moldavcki (30) proposed that $\mathrm{Al}_{2} \mathrm{O}_{3}$ inclusions in metal would not be removed by ANF-6 slag containing $30 \% \mathrm{Al}_{2} \mathrm{O}_{3}$. An equation for calculation of solution or dissolution time required has been proposed by V. A. Voronov et al. (31). However, the investigation (32) has shown that a round inclusion of radius $R$ located at the original position $(h, r)$ of the metal-slag interface will be transferred completed into the slag phase, when

$$
\Delta \mathrm{F}=\left(\sigma_{s-i}-\sigma_{m-i}\right) \cdot 2 \pi \mathrm{Rh}+\sigma_{m-s} \cdot \pi r^{2}<0
$$

where $\Delta F$ is the change of surface energy, or $\sigma_{s-j}+\left(\pi r^{2} / 2 \pi R h\right)$. $\sigma_{m-s}<\sigma_{m-i}$. As $\left(\pi r^{2} / 2 \pi R h\right)$ must be less than one and positive, and cannot be \pm 1 , Equations (15) and (16) cannot be estab1ished. Also it is concluded that Equation (17) can be used only for determining the direction of the movement of inclusions at certain positions. It is maintained that the condi- 
tions of Equation (18) must be fulfilled for the removal of the inclusions.

The removal of inclusions at times need not be 7 imited by the dissolution process and diffusion of solution products. At times the transfer rate of inclusions from within the 1iquid metal to the metal-slag interface can be slow. The above conclusions have been confirmed by the experimental results of ESR of Fe-AT alloy carried out with a slag composition of $63 \% \mathrm{CaF}_{2}, 30 \% \mathrm{Al}_{2} \mathrm{O}_{3}$ and $7 \% \mathrm{SiO}_{2}$ under argon atmosphere (32). The rate of the removal of inclusions increased with increasing $V[\mathrm{~A}] \mathrm{S}$ (Fig. 12) and the concentration of $\mathrm{Al}_{2} \mathrm{O}_{3}$ near the metal-slag interface was more than $30 \%$ owing to the oxidation of aluminum. Clearly, the removal of inclusions is not limited by the diffusion of $\mathrm{Al}_{2} \mathrm{O}_{3}$. The effect of voltage on the remelting behavior of the electrode tip and the removal rate of oxide inclusions are shown in Fig. 13. It is obvious that increasing the voltage promoted the transfer of inclusions from within the liquid metal to the metal-slag interface. In addition, the transfer rate of oxide inclusions from the side of metal to that of slag at the metal-slag interface owing to the effect of interfacial tensions is very fast. The time needed for complete transfer was shown to be about $10^{-6} \mathrm{sec}$ (33). Thus, the removal of inclusions should be controlled by the transfer rate of inclusions from within the liquid metal to the metal-slag interface.

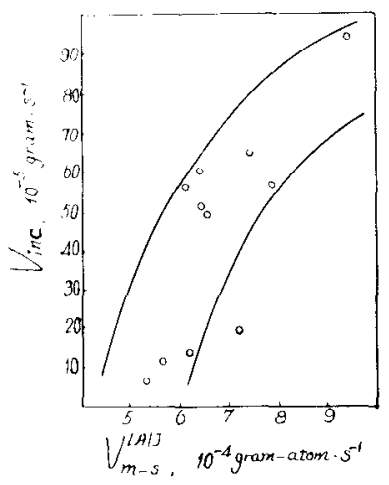

Fig. 12. Relation between rate of removal of alumina inclusions ( $V_{\text {inc }}$ ) and rate of aluminum oxidation pt

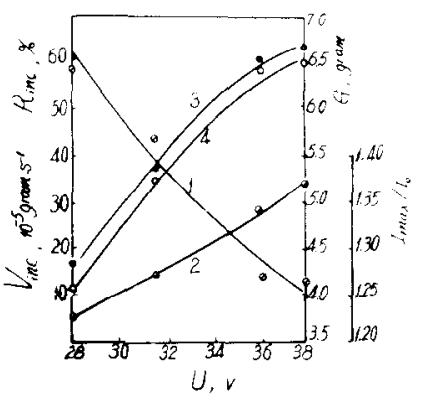

Fig. 13. Effect of voltage on remelting of electrode tip and removal of oxide inclusions

1 - droplet weight $G$

2 - I max $/ I_{0}$

3 - ratio of removal of oxide inclusions Rinc

4 - rate of removal of oxide inclusions $V$ inc 
It should be pointed out that a certain amount of oxides dissolved in molten alloy-steels and segregated during crystallization (18), and similar phenomena, has been observed in superalloys at the GiGi Haer Steel Plant. For instance, after remelting of alloy GH136 in mold of $550 \mathrm{~mm}$ in diameter, the total oxide inclusion decreased from $0.0079 \%$ to $0.0061 \%$, $\mathrm{SiO}_{2}$ decreased from $0.0012 \%$ to 0.00085 , but $\mathrm{Al}_{2} \mathrm{O}_{3}$ increased from $0.0030 \%$ to $0.0045 \%$. The change of the composition of oxide inclusions showed that some new inclusions formed during the solidification process.

\section{EFFECT OF HYDROGEN AND NITROGEN CONTENTS IN ELECTRODES}

The effect of various melting processes on the microstructures and properties of GH132 has been studied by this University, Da Ye Steel Plant and No. 5 Steel Plant of Shanghai $(34,35)$. It has been found that air melted GH132 electrodes were different from those vacuum melted in that they were less plastic at intermediate temperatures, Fig. 14. It has been suggested that one of the reasons for this can be a difference in hydrogen contents which, after forging in AAM + ESR metal and VIM + ESR metal, were found to be $6 \mathrm{ml} / 100 \mathrm{~g}$ and $1.5 \mathrm{ml} / 100 \mathrm{~g}$, respectively. They are $2 \mathrm{ml} / 100 \mathrm{~g}$ and $0.5 \mathrm{ml} /$ $100 \mathrm{~g}$, respectively, in the tensile samples. After vacuum heat treatment at $700^{\circ} \mathrm{C}$, the hydrogen content of AAM + ESR samples decreased to about $0.5 \mathrm{ml} / 100 \mathrm{~g}$, and the temperature range of low plasticity disappeared although the plasticity level remains lower than that of VIM + ESR samples (Fig. 14).

Investigations carried out in this University and the

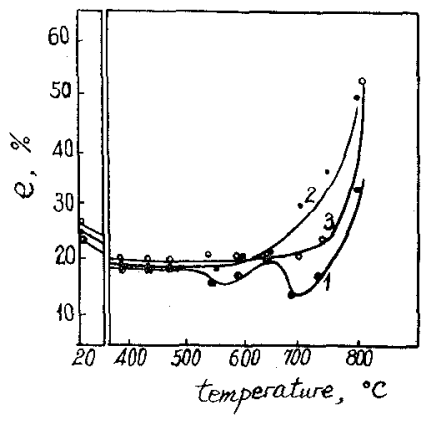

Fig. 14. Effect of test temperature on elongation of GH132 bar

$$
\begin{aligned}
& 1 \text { - AAM + ESR, 2ml } / 100 \mathrm{~g} \\
& \text { hydrogen } \\
& 2 \text { - VIM + EAR, } 0.5 \mathrm{ml} / 100 \mathrm{~g} \\
& \text { hydrogen } \\
& 3 \text { - AAM + ESR, } 0.5 \mathrm{ml} / 100 \mathrm{~g} \\
& \text { hydrogen }
\end{aligned}
$$


Steel Plant of Beijing (36) show that nitrogen in electrodes is detrimental to stress-rupture life and ductility for alloy GH36,

$$
\begin{aligned}
& \psi=43.6-81.2[N] \\
& \tau=252-1090[N]
\end{aligned}
$$

where $\psi$ is $\%$ reduction of area at $20^{\circ} \mathrm{C},[\mathrm{N}]$ is the nitrogen content of remelted metal which approximates to that of electrode, wt. $\%, \tau$ is the stress-rupture at $650^{\circ} \mathrm{C}$ under stress of $343 \mathrm{MN} / \mathrm{m}^{2}$.

It is very clear that the hydrogen and nitrogen contents in the electrodes used in the ESR of superalloys must be controlled carefulty.

\section{CONTROL OF FRECKLE SEGREGATION IN ESR SUPERALLOYS}

The nature of the freckle, the mechanism of $i$ ts formation and its influence on alloy properties have been studied at the Institute of Metal Research, Academica Sinica, Da Ye Steel Plant and others (37). The most important factor controlling the freckle formation is the depth of "mushy region" or the temperature gradient in this region. However, it should be mentioned that the uniformity of composition and microstructure of superalloys could be improved by controlling the contents of some elements, such as $\mathrm{Ti}$ and $\mathrm{C}$ in $\mathrm{GH} 37$ and $\mathrm{A} 1$ in GH135.

The influence of aluminum content on the freckle formation in ESR alloy GH135 is shown in Fig. 15.

\section{CONCLUSIONS}

1. The titanium loss in ESR of superalloys is mainly due to atmospheric oxidation of low valance titanium ions $\mathrm{Ti}^{3+}$ and subsequent reduction of high valance titanium ions $\mathrm{Ti}^{4+}$ by [Ti] during the ESR of the superalloys containing high titanium and low aluminum, such as GH132 and GH136. Ti ${ }^{3+}$ acts continuousiy as a transporter or oxygen via $\mathrm{Ti}^{4+}$ from atmosphere to metal. While $\left(\mathrm{TiO}_{2}\right)$ has an oxidizing effect on [ $\left.\mathrm{Ti}\right]$, [AI] content increases with corresponding increase of [ $\mathrm{Ti}]$ 


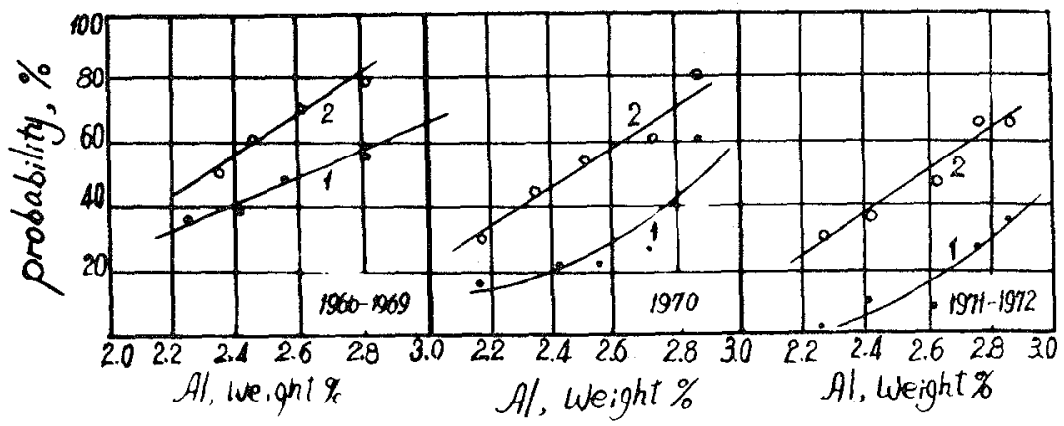

Fig. 15. Effect of aluminum content on the probability of freckle occurred in GH135 a1loy produced in various periods in a steel plant

\section{1 - bottom of ingot 2 - top of ingot}

Data of Institute of Metal Research, Academica Sinica

Toss at the bottom-end owing to the oxidation of [Ti] by $\left(\mathrm{Al}_{2} \mathrm{O}_{3}\right)$. The optimum content of $\mathrm{TiO}_{2}$ in original slag is 3$6 \%$. (MgO) increases the coefficients of activity of ( $\left.\mathrm{Ti}_{3} \mathrm{O}_{5}\right)$ and $\left(\mathrm{Al}_{2} \mathrm{O}_{3}\right)$ and decreases that of $\left(\mathrm{TiO}_{2}\right)$. The titanium loss is more affected by technological factors. Relatively high voltage and "Tive mold" result in a higher surface temperature of slag pool, a more rapid reoxidation of $\mathrm{Ti}^{3+}$ and, as a result, a greater loss of [Ti]. The $\mathrm{V}_{\mathrm{S}}^{\mathrm{O}}$ and $\mathrm{K}_{\mathrm{S}}^{\mathrm{Ti}} \mathrm{3}^{+}$are about two to three times larger in a "live moid" than in an insulated one. The control of the atmosphere above the slag is important.

2. The temperature distribution at the metal pool-slag interface which can be expressed by the equation $t=A e^{B} / d$ has significant influence on surface quality of ESR ingots. The surface quality of remelted ingots can be described in terms of the thickness change of slag skin during remelting process. The thickness of slag skin can be expressed as $\delta=B /\left(\right.$ lut $\left._{1}-\ln A\right)$. Surface quality is also sensitive to the heat transfer conditions and the current density distribution in slag pool, the liquidus of slag and 217 the factors affecting the temperature of the high temperature region of the slag pool.

3. The removal of oxide inclusions mainly occurs during the droplet formation at the electrode tip owing to intensive interaction between metal and slag. The condition for the removal of oxide inclusions is

$$
\Delta F=\left(\sigma_{s-j}-\sigma_{m-j}\right) \cdot 2 \pi R h+\sigma_{m-s} \cdot \pi r^{2}<0
$$


The removal of inclusions is not limited by the diffusion of solution products and the process of purification from inclusions is controlled by the transfer rate of inclusions from within the liquid metal to the metal-slag interface. It was found that some new inclusions formed during the ESR process. In order to minimize the size of inclusions and improve their distribution in metal, the solidification process must be appropriately controlled.

4. The quality of electroslag remelted alloys is affected by the consumable electrode quality, particularly the gas content in the electrodes. Therefore, it is necessary to make consumable electrodes by VIM or vacuum degassing process.

5. The occurrence of freckle can be reduced by controlling the contents of some elements, such as $\mathrm{Ti}$ and $\mathrm{C}$ in $\mathrm{GH} 37$ and $A 1$ in GH135.

\section{ACKNOWLEDGMENTS}

The authors are grateful to No. 5 Steel Plant of Shanghai, $X i$ Ning Steel Plant, GiGi Haer Steel Plant and Steel Plant of Beijing for cooperating and for supporting portions of the research effort. We think Professor T. Ko for his editorial assistance.

\section{REFERENCES}

1. G.K. Bhat, "Proceedings of the Fourth International Symposium on Electroslag Remelting Process," p. 196 (1973).

2. R.S. Cremisio, The Superalloys, Eds. C.T. Sims and W.C. Hage1, New York, p. 396 (1972).

3. C.X. Chen, Y. Wang, J. Fu and E.P. Chen, "A Study of Titanjum Loss in the Superalloys Containing High-Titanjum and Low-Aluminum During ESR Process," submitted to Acta Metallurgica Sinica.

4. J. Fu, C.X. Chen, E.P. Chen and Y. Wang, Acta Metallurgica Sinica, 15, No. 1, 44 (1979).

5. J. Fu, E.P. Chen, C.X. Chen and Y. Wang, "Effect of Temperature Distribution in the Molten Slag Pool on the Quality of Superalloys," submitted to Acta Metallurgica Sinica (1980).

6. M. Etienne and A. Mitche11, "Second International Symposium on Electroslag Remelting Technology Symposium Proceedings," Part 2 (1969). 
7. C.F. Kinghts and R. Perkins, Electroslag Refining, p. 35 (1973).

8. L.L. Gill and K. Harris, Electroslag Refining, p. 89 (1973).

9. K. Schwerdtfeger and W. Wepner, Ironmaking and Steelmaking, 5, No. 3, 135 (1978).

10. B. Korousić and W. Holzgruber, Berg-und Hüttenmannisch Monatschrifte, $\mathrm{Nr} .1$ (1978).

11. I. Barin and 0. Knacke, Thermochemical Properties of Inorganic Substances, pp. 584, 749 and 782 (1973).

12. G.K. Bhat and G.B. Tobias, U.S. Patent 3551137.

13. B.E. Paton et al., International Iron and Steel Congress, Vol. 3, No. 4, Special Metallurgical Treatment of Highgrade Steels, 4.2.2.6 (1974).

14. A. Metchel1 et a T., Electroslag Refining, p. 3 (1973).

15. A.H. Dilawari and J. Szekely, Met. Trans., 9B, No. 1, 77 (1978).

16. M. Kawakami et a1., Tetsu-To-Hagané, 63, No. 4, 599 (1977).

17. M. Kawakami et aT., Tetsu-To-Hagané, $\overline{63}$, No. 13, 2162 (1977).

18. J. Fu and C. Chu, Acta Metallurgica Sinica, 7, No. 3, 250 (1964).

19. J. Fu, C.P. Chen and C. Chu, Acta Metallurgica Sinica, 8 , No. $1,8(1965)$.

20. Z.B. Li, Y. Li, Y.W. Ye and Z.C. Song, Iron and Steel (China), No. 1 (1966).

21. G.A. Vachugov et a1., Bu11. TSEENCHM, No. 1 (1966).

22. P.P. Efseef and A.F. Filippov, IZV. AN SSSR, Meta71, No. 3, 57 (1968).

23. U.V. Latash and B.E. Medovar, Elektroshlak Pereplav, Moskva, 118 (1970).

24. Z.B. Li, W.H. Zhou, Y. Li, L.L. Yan and J.K. Huang, Iron and Steel (China), No. 1 (1980).

25. J. Fu, Y. Qu, etc., "Symposium on Electroslag Metallurgy, Beijing, 167 (1965).

26. S.A. Eodocovski and V.V. Panin, IZV. AN SSSR, Metall, No. 2, 115 (1968).

27. H.J. Klingelhöfer, P. Mathis and A. Chondhurg, Arch. für das Eisenhuttenwesen, 42, No. 5, 299 (1971).

28. B.A.R. Kay and R.J. Pomfret, J. Iron Steel Inst., 209, No. 12, 962 (1971).

29. D. Ya. Povoltski, V.A. Voronov and B.M. Nikitin, IZV. Vuz. ChM., 14, No. 12, 14 (1971).

30. 0.D. Moldavcki, IZV. AN SSSR, Meta11, No. 636 (1970).

31. V.A. Voronov, B.E. Nikitin and A.N. Prohorov, IZV. AN SSSR, Meta11, No. 3, 62 (1975).

32. J. Fu, Acta Metallurgica Sinica, 15, No. 4, (1979).

33. Yu. G. Gurevich, IZV, Vuz. Cher. Met., No. 8, 5 (1968). 
34. "The Effect of Various Melting Processes on the Microstructures and Properties of GH132," Report to the 2nd National Conference of Superalloys, Beijing University of Iron and Steel Technology, Da Ye Steel Plant and No. 5 Steel Plant of Shanghai, China (1976).

35. "The Effect of Hydrogen on Intermediate Temperature Ductility in GH132 Alloy," Report to the National Conference of Superalloys, Beijing University of Iron and Steel Technology, Da Ye Steel Plant and No. 5 Steel Plant of Shanghai, China (1979).

36. "The Effect of Nitrogen on the Microstructures and Properties of GH36 Alloy," Report to the 1st National Conference of Superalloys, Beijing University of Iron and Stee 1 Technology and Beijing Steel Plant, China (1974).

37. "Nature of the Freckle and Its Influence on Mechanical Properties in Several Superal1oys, "Research Report by the Institute of Metal Research, Academica Sinica, Da Ye Steel Plant and others, China (1976). 